ISSN: 2146-3042

DOI: $10.25095 /$ mufad.438778

\title{
Kredi Türlerinin Takipteki Krediler Oranına Etkisi: Varlık Temelli Krediler Yüksek Takipteki Krediler Oranı İçin Bir Kalkan Mı?
}

\author{
Ömer TEKŞEN* \\ Mustafa ÇELİK**
}

\section{$\ddot{O Z E T}$}

Bu çalışma, mevduat bankaları bazında farklılaşan kredi tercihlerinin, takipteki krediler oranı üzerindeki muhtemel etkisini tespit etmeyi amaç edinmektedir. Bu kapsamda en büyük 10 Türk mevduat bankasının 2006-2016 yılları arasındaki verileri üzerinden panel veri analizi çalışması gerçekleştirilmiştir. Analiz sonuçlarına göre, konut ve ticari taşıt kredileri ile takipteki krediler oranı arasında negatif; taşıt kredileri ile takipteki krediler oranı arasında pozitif yönde bir ilişkinin bulunduğu neticesine varılmıştır. Ayrıca kontrol değişkeni olarak analize dahil edilen enflasyon, önceki dönem takipteki krediler oranı ve aktif büyüklüğ̈̈ değişkenlerinin de takipteki krediler oranı üzerinde anlaml ve pozitif; kriz değişkeninin ise anlamlı ve negatif bir etkisinin olduğu sonucuna varılmıştır.

Anahtar Kelimeler: Takipteki Krediler Oranı, Kredi Türleri, Varlık-Temelli Krediler.

JEL Sinıflandirmasi: G21, G33.

The Effect of Loan Types on Non-Performing Loans Ratio: Is Asset-Based Loans a Shield for High Non-Performing Loans Ratio?

\section{ABSTRACT}

This paper aims to determine the possible relationship between loan preferences of banks and non-performing loan ratio. In this context, 10 biggest Turkish deposit banks' financial tables between 2006-2016 years are taken into consideration and panel data analysis is conducted on this data. As a result of the analysis, it is concluded that there is a negative relationship between mortgage \& commercial vehicle loans and non-performing loans ratio and positive relationship between vehicle loans' and non-performing loans ratio. Also, as control variables inflation, previous term NPL ratio and asset size have positive and crisis variable has negative and statistically meaningful impact on non-performing loans ratio.

Keywords: Non-Performing Loans Ratio, Loan Types, Asset Based Loans.

Jel Classification: G21, G33.

\footnotetext{
* Doç. Dr. Ömer Tekşen, Mehmet Akif Ersoy Üniversitesi, İktisadi ve İdari Bilimler Fakültesi, omerteksen@mehmetakif.edu.tr

** Arş. Gör. Mustafa Çelik, Mehmet Akif Ersoy Üniversitesi, İktisadi ve İdari Bilimler Fakültesi, mcelik@mehmetakif.edu.tr
} 


\section{GíRiş}

2009 finansal krizinden sonra dünya genelinde pek çok bankanın artan kredi riski dolayısıyla zor zamanlar geçirmiş olması, son dönemde kredi riski yönetiminin önemini daha da artırmıştır. Son finansal kriz, kötü bir kredi portföyünün banka ve finansal sistem kırılganlığını beraberinde getirdiğini haber vermiştir. Bu noktada bankaların kredi kalitelerini tespit etmede kullanılan takipteki krediler oranı bankalar için önemli bir gösterge haline gelmiştir. Yüksek takipteki krediler oranına sahip bankalar ödeme güçlüğüne düşmeye daha yakın olmakta; söz konusu bankalar bu konuda güçlük yaşamasa dahi yüksek takipteki krediler oranı bankaların performans düzeylerini aşağı çekmektedir. Sonuçta ise yüksek takipteki krediler oranı finansal sektör oyuncuları ile birlikte tüm ekonomiyi negatif anlamda etkileyebilmektedir (Curak, Pepur ve Poposki, 2013:45).

Günümüzde, ekonomideki artık fonların kârsız alanlara sıkışıp kalmasının önüne geçmek için takipteki krediler oranının aşağı çekilmesi önemli bir amaç haline gelmiştir. Söz konusu amacın gerçekleştirilememesi durumunda, bankaların likidite sıkıntıları ve geri dönmeyen alanlara aktarılan fonlar ekonomik büyümeye zarar vermekte ve verimliliği düşürmektedir (Hou, 2007).

Türkiye'de bankacılık sektörünün takipteki krediler oranı ile yıllık Gayri Safi Yurtiçi Hasıla (GSYİH) büyüme verileri karşılaştırıldığında (Şekil 1), iki büyüklük arasında kriz dönemlerinde ters yönlü bir ilişkinin mevcut olduğu görülmektedir. Takipteki krediler oranı 2001 ve 2009 gibi kriz yıllarında zirve yapmakta; diğer yıllarda ise istikrarlı bir büyüme mevcut ise aşağı yönlü bir seyirde devam etmektedir. $\mathrm{Bu}$ yönüyle değerlendirildiğinde takipteki krediler oranının Türkiye ekonomisinin genel gidişatı yönünde de ipuçları verme potansiyeline sahip olduğu görülmektedir.

Ekonominin geneli üzerindeki etkisi sebebiyle son dönemdeki çalışmalarda takipteki krediler oranı üzerinde etkili olan faktörler incelenmekte ve bu faktörler banka içi ve banka dışı faktörler olarak ikiye ayrılmaktadır (Makri, Tsagkanos ve Bellas, 2014:194). Takipteki krediler oranı için belirleyici faktörlerin tespiti sayesinde, kredi riskinin etkin yönetiminde uygulanması gereken politika araçları daha kolay belirlenebilmektedir. Bu çalışmada, mevcut çalışmalarda yer alan ve takipteki krediler oranı üzerinde etkisi olabileceği düşünülen değişkenlerin üzerine bankaların sahip oldukları kredi yapısına ilişkin değişkenler eklenerek hem daha kapsamlı bir analize gidilmiş hem de bankaların müşterilere sunduğu kredi türlerinin takipteki krediler oranı üzerindeki etkisine yer verilmeye çalışılmıştır. 


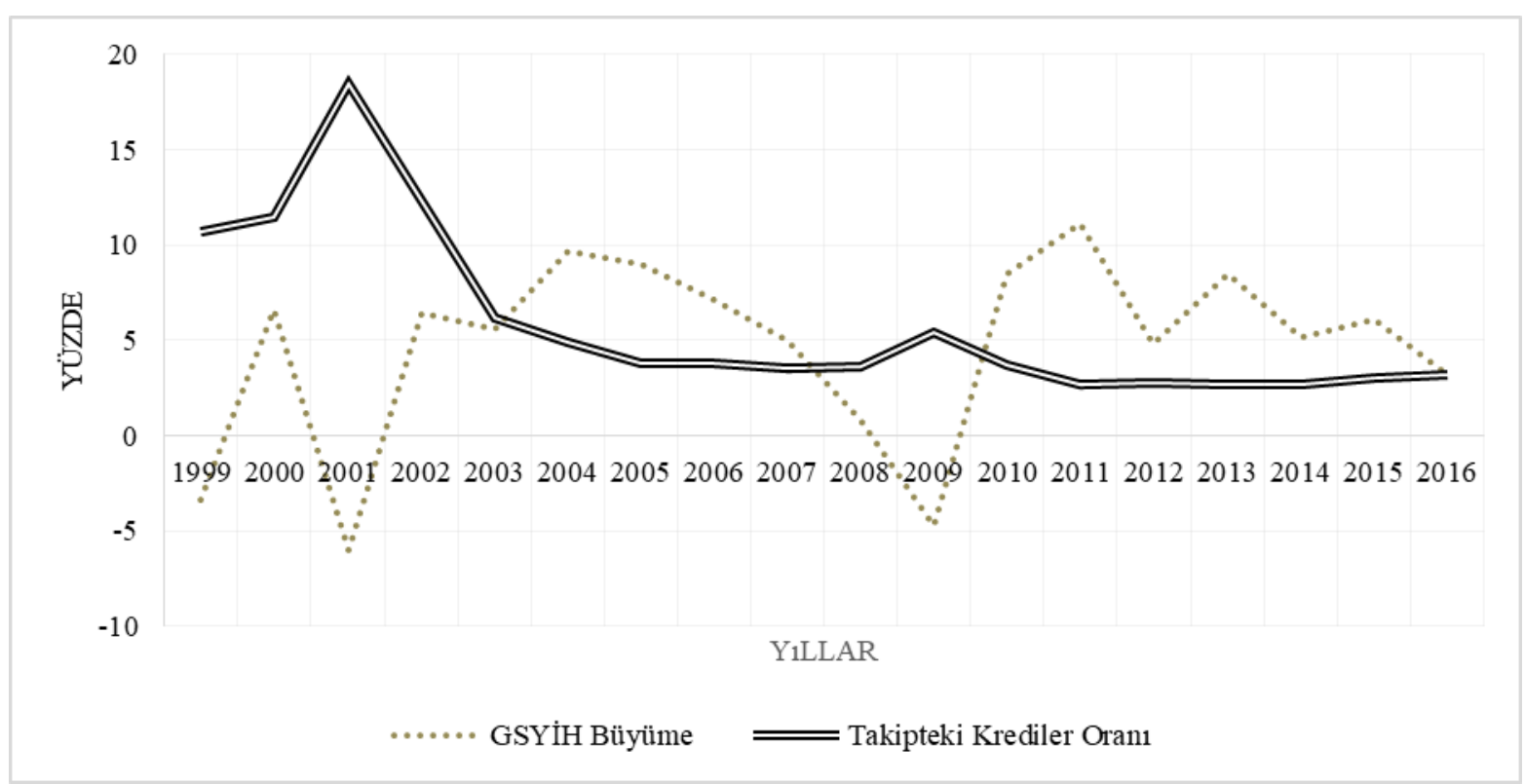

Kaynak: www.tbb.org.tr / www.tuik.gov.tr

Şekil 1. Büyüme- Takipteki Krediler İlişkisi

Çalışmanın amacı doğrultusunda ikinci bölümde takipteki kredilerin belirleyicileri üzerine bir literatür taramasına gidilmiş; üçüncü bölümde uygulanan panel veri regresyonu açıklanmış ve sonuçlar okuyucu ile paylaşılmış; dördüncü ve son bölümde ise çalışmanın uygulama kısmı üzerinden elde edilen genel çıkarımlar ve söz konusu çıkarımların sonucu olan önerilere yer verilmiştir.

\section{LITERATÜR TARAMASI}

Literatürde yer alan takipteki krediler oranına ilişkin çalışmalar, takipteki krediler oranının belirleyicileri üzerine yoğunlaşmaktadır. Bankacılık sektöründe genel takip oranını etkileyen makro değişkenlerin analiziyle sınırlı çalışmalar var olduğu gibi; her bir bankanın takipteki krediler oranı üzerinde etkili olan mikro belirleyiciler ve bankaya özgü değişkenleri de içeren çalışmalar bulunmaktadır.

Takipteki kredilere ilişkin öncü çalışmalardan Keeton ve Morris (1987), takipteki kredilerin temel belirleyicisinin yerel ekonomik koşullar ve tarım, enerji gibi sektörlerin beklenmedik kötü performansları olduğu sonucuna varmıştır. Bununla birlikte söz konusu temel belirleyici olmaksızın bir analiz yapılsa dahi bankalar arasında farklı takipteki krediler oranlarının görülmesini ise bazı bankaların farklılaşan risk iştahlarına bağlamıştır. Takipteki kredilerin azaltılmasının ise kredilerin farklı endüstriler bazında farklılaştırılması (tüm yumurtaların aynı sepete koyulmaması) ve risk iştahının makul seviyeye çekilmesi ile mümkün olacağ 1 yönünde görüş bildirmiştir.

Berger ve DeYoung (1997) ise, takipteki kredilerin nedenlerine ilişkin geliştirdikleri dört farklı hipotezi Granger Nedensellik Testi ile analiz etmiş ve maliyet etkinliğinin takipteki kredileri azalttığı, bununla birlikte sermaye yapısındaki zayıf görünümün takipteki krediler oranını yukarı çektiğini gözlemlemiştir. 
Breuer (2006), takipteki kredilerin belirleyicilerini toplumsal düzen ve insan ilişkilerinde aramıştır. Çalışmada banka ve müşteriler arasındaki potansiyel çıkar çatışmalarının azaltılması ve yolsuzluk/bozulmanın önlenmesi ile takipteki kredilerin azaltılabileceği sonucuna varmıştır.

Takipteki kredilere ilişkin öncü çalışmalar sonrasında, son dönemde takipteki kredilerin mikro ve makro belirleyicilerin tespitine yönelik çalışmalar yoğunluk kazanmıştır.

Messai ve Jouini (2013), İtalya, Yunanistan ve İspanya'daki 85 banka üzerinde 20042008 yılları arasını kapsayan analizleri neticesinde takipteki krediler oranının, GSYİH büyümesi, işsizlik oranı, reel faiz oranı gibi makro değişkenlerin yanında; aktif karlılığı ve kredi karşılıklarının toplam kredilere oranı gibi bankaya özgü niteliklerden etkilendiği sonucuna varmıştır.

Skarica (2014), Avrupa'nın gelişmekte olan ülkelerinde faaliyet gösteren bankalar üzerinde 2007-2012 yıllarını kapsayan analizinde, GSYİH büyümesi, enflasyon ve işsizlik gibi makro faktörlerin takipteki krediler üzerinde etkisini tespit ederken; bankalara ve ülkelere özgü faktörlerin ise takipteki krediler oranı üzerinde istatistiki olarak anlamlı bir etkisini gözlemleyememiştir.

Makri, Tsagkanos ve Bellas (2014), 2000-2008 yılları arasında Euro bölgesinde yer alan bankaların verilerini kullandıkları çalışmada devletin borçlanma düzeyi, işsizlik, GSYİH büyümesi gibi makro değişkenler ile birlikte sermaye yeterliliği, önceki dönem takipteki kredi oranı ve özkaynak kârlılığı gibi bankaya özgü değişkenlerin takipteki krediler oranı üzerinde istatistiki olarak anlamlı bir etkisinin bulunduğunu göstermiştir.

Tanaskovic ve Jandric (2015), Orta, Doğu ve Güneydoğu Avrupa ülkeleri bankalarının 2006-2013 yılları arasındaki verileri üzerinden yaptığı çalışmada, ülkeye özgü faktörler ve genel makro faktörlerin takipteki krediler üzerindeki etkisini araştırmıştır. Çalışmada büyüme ve döviz kuru gibi makro değişkenler ile birlikte, ülkeye ve bankaya özgü finansal sektör derinliği ve döviz kredilerinin büyüklüğü gibi değişkenlerin takipteki krediler üzerindeki anlamlı etkisi olduğunu ileri sürmüştür.

Rajha (2016), 2008-2012 yılları arasında Ürdün Bankacılık sektörünü incelediği çalışmasında, GSYİH büyümesi, enflasyon oranı ve küresel ekonomik kriz gibi makro değişkenlerin yanında; bir önceki dönemin takipteki krediler oranı ve kredilerin toplam aktiflere oranı gibi bankaya özgü faktörlerin takipteki krediler üzerinde istatistiki olarak anlamlı etkisi bulunduğu sonucuna varmıştır.

Anastasiou, Louri ve Tsionas (2016a), Euro bölgesinde yer alan bankalar üzerinde 1990-2015 yılları arasını kapsayan analizleri neticesinde büyüme ve işsizlik gibi makro değişkenler ile birlikte bankaların yönetim becerileri ve risk tercihlerinin takipteki krediler oranı üzerindeki etkisinin istatistiksel açıdan anlamlı olduğu sonucuna varmıştır. Ayrıca, kişisel gelir vergisi ve çıktı açığının da takipteki krediler oranının belirleyicisi olduğu yönünde literatüre katkıda bulunmuştur.

Anastasiou, Louri ve Tsionas (2016b), 2003-2013 y1lları arasını kapsayan ve Euro bölgesi ülkeleri ile az gelişmiş ülkeler üzerinde gerçekleştirdikleri analizlerinde, faiz marjları 
ve finansal durumun az gelişmiş ülkelerde takipteki krediler için önemli bir değişken olduğunu; bununla birlikte Euro bölgesi için büyümenin takipteki krediler üzerinde anlamlı bir değişken olduğunu tespit etmiştir. Yine az gelişmiş ülkeler için yönetim kalitesi, ahlaki risk seviyesi ve banka büyüklüğünün takipteki krediler üzerinde anlamlı bir etkisinin olduğu sonucuna varmıştır. Yine bu ülke grupları arasında takipteki krediler üzerinde etkili faktörlerin, ülke grupları özelinde takipteki krediler oranını etkileme güçlerinin farklılaştığı sonucuna varmıştır.

Mensah, Marbuah ve Marbuah (2017), Gana bankacılık sektöründe küresel kriz dönemini kapsayan (2007-2009) analizlerinde, bir önceki yılın takipteki krediler oranı, kredi riski, banka büyüklüğü ve kredi büyümesi gibi mikro faktörlerin yanında enflasyon, borç stoğu, büyüme ve reel faiz oranı gibi makro değişkenlerin de takipteki krediler üzerinde istatistiki olarak anlamlı bir etkisinin bulunduğunu tespit etmiştir.

Takipteki krediler oranına ilişkin Türkiye'deki çalışmaların da literatüre paralel bir biçimde takipteki krediler oranının belirleyicileri üzerine yoğunlaştığı görülmektedir. Farklı makro göstergeler ve bankaya özgü değişkenlerin takipteki krediler oranına etkisi Türkiye çalışmalarının konusunu oluşturmaktadır.

Macit (2012), Türkiye'de faaliyet gösteren bankalar üzerinde 2006-2010 y1lları arasın1 kapsayan analizinde özkaynak/toplam akifler oranı, net faiz marjı ve krediler/toplam aktifler oranı gibi mikro değişkenlerin yanında; büyüme ve döviz kuru gibi makro değişkenlerin de takipteki krediler üzerindeki etkisini ortaya koymuştur.

Macit ve Keçeli (2012), Türkiye'de faaliyet gösteren katılım bankaları üzerinde 20052011 yıllarını kapsayan çalışmasında, kredi/aktif oranı, aktif büyüklüğü ve büyümenin takipteki krediler üzerinde istatistiki olarak anlamlı negatif etkisini tespit etmiştir.

Vatansever ve Hepşen (2013), Türk bankacılık sektörü üzerinde, 2007-2013 yılları arasını kapsayan çalışmasında, bankaların verimsizlik oranları, özkaynak kârlılık oranı ve sermaye yeterlilik oranı gibi bankaya özgü niteliklerin yanı sıra; endüstriyel verimlilik endeksi, BIST100 endeksi ve işsizlik oranı gibi makro değişkenlerin takipteki krediler oranı için belirleyiciler olduğu sonucuna varmıştır.

Yağcılar ve Demir (2015), Türkiye'de faaliyet gösteren ticari bankalar üzerinde, 20022013 yılları arasını kapsayan çalışmasında, borsada işlem görme, ölçek, kredi/mevduat oranı, likidite ve aktif karlılığ 1 değişkenlerinin takipteki krediler üzerinde negatif; büyüme, faiz oranı, sermaye yeterliliği rasyosu ve yabanc1 sahipliğinin takipteki krediler üzerinde pozitif bir etkisinin olduğu sonucuna varmıştır.

Abidoğlu ve Aytekin (2016), Türk mevduat bankaları üzerinde 2002-2014 y1lları arasını kapsayan analizleri neticesinde, bir önceki dönem takipteki krediler oranı, net faiz marjı, sermaye yeterliliği ve ödeme gücü oranlarının takipteki krediler üzerinde negatif; kredilere uygulanan faiz, kredi/mevduat oranı, etkinsizlik ve faaliyet etkinliği değişkenlerinin ise takipteki krediler üzerinde pozitif bir etkisinin bulunduğu yönünde çıkarımda bulunmuştur. 
Us (2016), 2002-2015 yılları arasını kapsayan analizinde Türk bankacılık sektöründe takipteki krediler oranının belirleyicilerinin önceki dönem takipteki krediler oranı, verimlilik, varlık büyüklüğü, büyüme, enflasyon, politika faizi, döviz kuru ve 2009 yılı finansal krizi olduğu sonucuna varmıştır. Ayrıca söz konusu çalışmada takipteki krediler oranını etkileyen faktörlerin kriz öncesi ve kriz sonrası dönemde farklılaştığını ortaya koymuştur.

Us (2017), 2002-2013 yılları arasını kapsayan analizinde Türk bankacılık sektöründe takipteki kredilerin belirleyicilerini sahiplik yapısı ayrımıyla belirlemeyi amaçlamıştır. Söz konusu çalışmada devlet, özel sektör ve yabancı yoğunluklu sermaye yapısına sahip bankalar için takipteki krediler oranı belirleyicilerinin farklılaştığı sonucuna varmıştır.

\section{TÜRK MEVDUAT BANKALARINDA KREDİ TERCIHLERININ TAKIPTEKI KREDILER ORANINA ETKISI}

\subsection{Veri Seti ve Ekonometrik Yöntem}

Çalışmada, takipteki krediler oranı üzerinde etkili olan kredi türü değişkenlerinin tespit edilmesi amaciyla, aktif büyüklügü sıralamasında ilk 10 'da yer alan Türk mevduat bankaları üzerinde 2006-2016 y1lları arasını kapsayan bir panel veri regresyonu analizine gidilmiştir. Çalışmanın 10 banka ve 11 dönemi içeren bir panel veri üzerinden gerçekleştirilmesi ve takipteki krediler oranının belirleyicileri üzerine bir analizi içermesi sebebiyle panel veri regresyonu çalışmada benimsenen yöntem olmuştur.

Çalışmada kullanılan panel veri, birey, firma, aile, ülke vb. yatay kesit gözlemlerin belli bir dönemi içerecek şekilde bir araya getirilmesi ile oluşan veri türüdür. Zaman serisi ve yatay kesit veriler üzerinden gerçekleştirilen analizler kimi ekonomik ve finansal olayların açıklanmasında tek boyutlu yapısı sebebiyle yetersiz kaldığından, panel veri ekonometrik analizlerde kullanışı bir veri türü olarak öne çıkmaktadır (Yerdelen Tatoğlu, 2016: 2-3). Çalışmada kullanılan regresyon analizi ise, bir veya birden fazla değişkenin değerlerinde meydana gelecek aşağı-yukarı yönlü değişmelerin bir başka değişkenin (bağımlı değişkenin) değerinde değerinde meydana gelecek değişmelere olan etkisini tespit etmeye yönelik bir analizdir (Sevüktekin, 2013:231-232). Panel veri üzerinden çeşitli tekniklerle gerçekleştirilen regresyon analizi de panel veri regresyonunu oluşturmaktadır

Çalışmaya dahil edilen bankaların listesi aşağıdaki gibidir:

1-Türkiye Cumhuriyeti Ziraat Bankası A.Ş.

2-Türkiye İş Bankası A.Ş.

3-Türkiye Garanti Bankası A.Ş.

4-Akbank T.A.Ş.

5-Yapı ve Kredi Bankası A.Ş.
6-Türkiye Halk Bankası A.Ş.

7-Türkiye Vakıflar Bankası T.A.O.

8-Finans Bank A.Ş.

9-Denizbank A.Ş.

10-Türk Ekonomi Bankası A.Ş. 
Çalışmada yer alan bankaların tümü mevduat bankaları olup farklı büyüklükler bazında Türk mevduat bankaları içerisindeki payları Şekil 2'de sunulmuştur. Söz konusu şekil incelendiğinde örneklem bankalarının pek çok büyüklük bazında sektörün önemli bir kısmını oluşturduğu ve dolayısıyla sektörü yansıtma kapasitesine sahip olduğu çıkarımı yapılabilir.

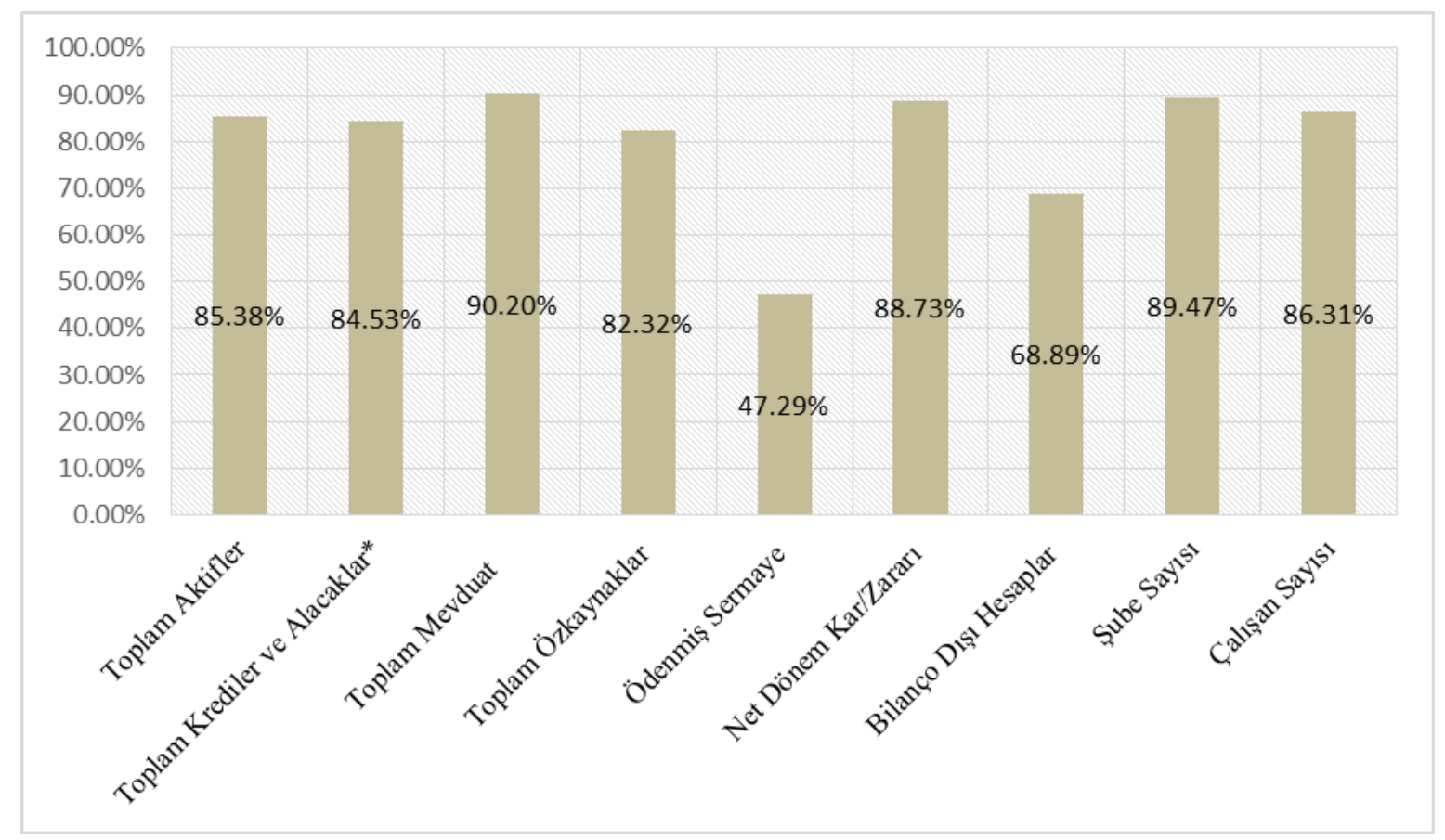

Kaynak: www.tbb.org.tr

Şekil 2. Örneklem Bankalarının Türk Mevduat Bankaları İçerisindeki Payı

Çalışmada kullanılan değișkenleri iki kısımda incelemek mümkündür. Birinci kısım değişkenler Us(2016)'un çalışmasında yer verdiği ve Türk bankacılık sektöründe takipteki krediler oranı üzerinde istatistiki olarak anlamlı etkisi bulunan değişkenlerdir. Söz konusu değişkenler Tablo 1'de sunulmuştur. İkinci kısım değişkenler ise çalışmanın amacı doğrultusunda bankaların finansal tabloları üzerinden elde edilen kredi türlerinin ana kredi kalemleri içerisindeki paylarını gösteren değişkenlerdir. Söz konusu değişkenler de Tablo 2'de sunulmuştur. Son olarak çalışmanın bağımlı değişkeni bankaların takipteki krediler oranıdir (Tablo 3).

Tablo 1. Kontrol Değişkenleri

\begin{tabular}{|c|c|c|}
\hline Değişken & Açıklama & Sembol \\
\hline $\begin{array}{l}\text { Bir Önceki Y1l Takipteki } \\
\text { Krediler Oran } 1\end{array}$ & $\begin{array}{l}\text { Takipteki Krediler }{ }_{\mathrm{t}-1} / \text { Toplam Kredi Ve } \\
\text { Alacaklar } \mathrm{I}_{\mathrm{t}-1}\end{array}$ & Takıplag1 \\
\hline Banka Verimliliğ ${ }^{1}$ & $\begin{array}{l}\text { Diğer Faaliyet Giderleri } i_{\mathrm{t}-1} / \text { Toplam } \\
\text { Varlıklar }_{\mathrm{t}-1}\end{array}$ & Digerfaaliyetgid \\
\hline Büyüklük ${ }^{1,2}$ & Ln(Toplam Varlıklar $/$ Gsyih $\left._{t}\right)$ & Lnaktıf \\
\hline Kriz Değişkeni & $\begin{array}{ll}\mathrm{T}>2008 & 1 \\
\mathrm{~T}<2009 & 0\end{array}$ & Dumcrisis \\
\hline Büyüme $^{2}$ & Gsyih Büyümesi $i_{t-1}$ & Buyume \\
\hline Enflasyon $^{2}$ & Tüfe $_{t-1}$ & Enf \\
\hline
\end{tabular}




\begin{tabular}{|c|c|c|}
\hline Döviz Kuru ${ }^{2}$ & Ln(Sepet Kur $\left.{ }_{\mathrm{t}-1}\right)$ & Tldeğer \\
\hline Politika Faizi ${ }^{3}$ & $\begin{array}{c}\text { (Geç Likidite Borç Verme Orant }{ }_{\mathrm{t}}-\text { Geç } \\
\text { Likidite Borç Verme Orant }\end{array}$ & Pfaiz \\
\hline Kaynak: ${ }^{1}$ www.tbb.gov.tr & ${ }^{2}$ www.tuik.gov.tr $\quad{ }^{3}$ www.tcmb.gov.tr & \\
\hline
\end{tabular}

Tablo 2. Politika Değişkenleri

\begin{tabular}{|c|c|c|}
\hline Değişken & Açılama & Sembol \\
\hline Konut Kredileri & Konut Kredileri $_{\mathrm{t}-1} /$ Tüketici Kredileri $\mathrm{t}_{\mathrm{t}-1}$ & Konut \\
\hline İhtiyaç Kredileri & Ln(İhtiyaç Kredileri $\mathrm{t}_{\mathrm{t}-1} /$ Tüketici Kredileri ${ }_{\mathrm{t}-1}$ ) & Lnihtiyac \\
\hline Taşıt Kredileri & Taşıt Kredileri $\mathrm{t}_{\mathrm{t}-1} /$ Tüketici Kredileri $\mathrm{t}_{\mathrm{t}-1}$ & Tasit \\
\hline İşyeri Kredileri & İşyeri Kredileri $_{\mathrm{t}-1} /$ Ticari Kredileri $_{\mathrm{t}-1}$ & Isyer1 \\
\hline Ticari İhtiyaç Kredileri & Tic. İhtiyaç Kredileri $\mathrm{t}_{\mathrm{t}-1} /$ Ticari Kredileri $_{\mathrm{t}-1}$ & Tihtıyac \\
\hline Ticari Taşıt Kredileri & Tic. Taşıt Kredileri ${ }_{\mathrm{t}-1} /$ Ticari Kredileri $\mathrm{t}_{\mathrm{t}-1}$ & Ttasit \\
\hline Özel Sektör Kredileri & Özel Sektör Kredileri $_{\mathrm{t}-1} /$ Toplam Krediler $_{\mathrm{t}-1}$ & Ozel \\
\hline Yurtiçi Kredileri & Yurtiçi Kredileri $_{\mathrm{t}-1} /$ Toplam Krediler $_{\mathrm{t}-1}$ & Yurtic1 \\
\hline \multicolumn{3}{|l|}{ Kaynak: www.tbb.gov.tr } \\
\hline
\end{tabular}

Tablo 3. Bağımlı Değişken

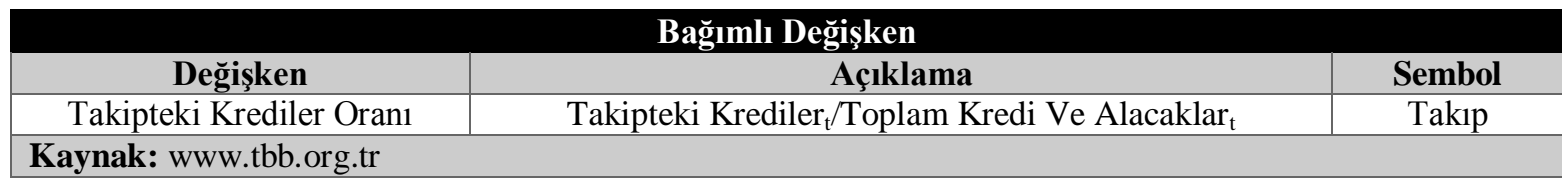

Verilerin analiz edilmesinde benimsenen panel veri regresyonu yönteminin uygulanabilmesi için temel koşul, seri ve panellerin durağan olmasıdır. Aksi halde analizde kullanılacak olan sabit etkiler modeli, sahte nedensellik sebebiyle yanlı ve hatalı sonuçlar verecektir (Rinaldi ve Sanchis-Arellano, 2006:20). Panel verilerinde durağanlığın test edilmesi için yatay kesit bağımsızlığı altında uygulanabilen Levin, Lin ve Chu (2002) ve Im, Pesaran ve Shin (2003) testleri kullanılmış ve elde edilen sonuçlar Tablo 4'te sunulmuştur. Yine zaman serilerinde durağanlığın test edilmesi için Augmented Dickey-Fuller (ADF) testleri kullanılmış ve elde edilen sonuçlar Tablo 5'te sunulmuştur (Dickey ve Fuller,1979).

Tablo 4. Panel Birim Kök Testleri

\begin{tabular}{|c|c|c|}
\hline Değişkenler & IPS & LLC \\
\hline Takipteki Krediler Oranı & $0.0016^{* * *}$ & 0.4887 \\
\hline Konut Kredileri/Tüketici Kredileri & $0.0613^{*}$ & 0.2641 \\
\hline İhtiyaç Kredileri/Tüketici Kredileri & $0.0241^{* *}$ & $0.0877^{*}$ \\
\hline Taşı Kredileri/Tüketici Kredileri & $0.0000^{* * *}$ & $0.0000^{* * *}$ \\
\hline İşyeri Kredileri/Ticari Krediler & 0.7427 & $0.0001^{* * *}$ \\
\hline Ticari İhtiyaç Kredileri/Ticari Krediler & 0.1554 & $0.0000^{* * *}$ \\
\hline Ticari Taşıt Kredileri/Ticari Krediler & $0.0021^{* * *}$ & $0.0012^{* * *}$ \\
\hline Özel Sektöre Kullandırılan Krediler/Toplam Kredi Ve Alacaklar & 0.1472 & $0.0303^{* *}$ \\
\hline Yurt İçine Kullandırılan Krediler/Toplam Kredi Ve Alacaklar & $0.0002^{* * *}$ & $0.0000^{* * *}$ \\
\hline
\end{tabular}




\begin{tabular}{|c|c|c|}
\hline Diğer Faaliyet Giderleri/Toplam Aktifler & 0.2062 & $0.0000 * * *$ \\
\hline Toplam Aktifler/Gsyih & 0.5560 & $0.0000 * * *$ \\
\hline $\begin{array}{l}\text { Tablo testlerin p değerlerini içermektedir. } \\
* \quad \mathrm{p}<0.1 \quad * * * \mathrm{p}<0.01\end{array}$ & & \\
\hline
\end{tabular}

Tablo 4 incelendiğinde panel değişkenlerin birim kök içerdiği (durağan olmadığı) yönündeki $\mathrm{H}_{0}$ hipotezinin uygulanan testlerden en az birinde reddedilebildiği görülmektedir. Dolayısıyla değişkenlerin birim kök içermediği sonucuna varmak mümkündür. Bununla birlikte ihtiyaç kredileri ve aktif büyüklüğü değişkenlerinin yapılan ilk testlerde birim kök içerdiği sonucuna varılmıştır. Söz konusu değişkenlerin logaritması alınarak oluşturulan yeni değişkenler vasıtasıyla Tablo 4'te yer alan $\mathrm{p}$ değerlerine ulaşılmıştır.

Tablo 5. Zaman Serisi Birim Kök Testleri

\begin{tabular}{|c|c|}
\hline Değişkenler & ADF \\
\hline Buyume & $0.0542 *$ \\
\hline Enflasyon & $0.0162 * *$ \\
\hline Politika Faizi & $0.0392 * *$ \\
\hline TL Değer & $0.0169 * *$ \\
\hline $\begin{array}{l}\text { Tablo testlerin } \mathrm{p} \text { değerle } \\
* \quad \mathrm{p}<0.1\end{array}$ & \\
\hline
\end{tabular}

Tablo 5 incelendiğinde zaman serisi değişkenlerinin birim kök içerdiği (durağan olmadığı) yönündeki $\mathrm{H}_{0}$ hipotezinin uygulanan testlerde reddedilebildiği görülmektedir. Dolayısıyla değişkenlerin durağan olduğu sonucuna varmak mümkündür. Bununla birlikte politika faizi değişkeninin yapılan ilk testte birim kök içerdiği sonucuna varılmış; söz konusu problem birinci farkların alınması yoluyla çözülmüş ve Tablo 5'teki p değerlerine ulaşılmıştır.

Panel veri regresyon denkleminin oluşturulmasında, sabit terim, hata terimi ve eğim katsayısı hakkındaki varsayımlara dayalı olarak sabit etkiler ya da tesadüfi etkiler yöntemine başvurulur (Gujarati, 2004:640). Hangi yöntemin kullanılacağı yönündeki karar ise Hausman testi ile gerçekleştirilir. Söz konusu testin yokluk hipotezi, açıklayıcı değişkenler ile birim/zaman etki arasında bir korelasyonun bulunmadığı yönündedir. Hipotezde belirtilen yargının doğru olması durumunda iki yöntemin arasındaki farkın çok küçük olacağ dolayısıyla tesadüfi etkiler modelinin kullanımının daha etkin sonuçlar vereceği kanısına varılır. Hipotezin reddedilmesi durumunda ise sabit etkiler modelinin benimsenmesi doğru olacaktır (Tatoğlu,2016:185).

Tablo 6. Hausman Testi Sonuçları

\begin{tabular}{|c|c|c|c|}
\hline & \multicolumn{2}{|c|}{ Hausman Testi } \\
\hline Test Özeti & Ki-Kare İstatistiği & $\begin{array}{c}\text { Ki-Kare Serbestlik } \\
\text { Derecesi }\end{array}$ & Olasılık \\
\hline Cross-Section Random & 136.77 & 16 & 0.0000 \\
\hline
\end{tabular}

Tablo 6 incelendiğinde, $\mathrm{p}$ değerinin 0.0000 olduğu, Hausman testi $\mathrm{H}_{0}$ hipotezinin reddedildiği ve dolayısıyla panel veri regresyon denkleminin tahmin edilmesinde benimsenmesi gereken yöntemin sabit etkiler modeli olduğu görülmektedir. 
Örneklemin, değişkenlerin ve benimsenecek yaklaşımın belirlenmesinin ardından çalışmada kullanılacak olan model aşağıdaki gibi ifade edilebilir:

$$
\begin{aligned}
& \text { Takipteki Krediler Orami }{ }_{i t}=\beta_{i t}+\sum_{k=1}^{K} \beta_{k} \text { Kontrol Değișkenleri } i_{k i(t-1)}+ \\
& \sum_{p=1}^{p} \beta_{p} \text { Politika Değișkenleri } i_{p i(t-1)}+e_{i t}
\end{aligned}
$$

Model cari yıl içerisindeki takipteki krediler oranını daha önceden tahmin edebilmek amacıyla bir önceki yıl değişkenlerini bağımlı değişken olarak kabul etmektedir. Us(2016)'nın çalışmasında yer verilen bankaya özgü ve makro değişkenler kontrol değişkeni ve kredi türlerinin ana kredi kalemleri içerisindeki payları da politika değişkeni olarak belirlenmiştir.

Tablo 7. Tanımlayıcı İstatistikler

\begin{tabular}{|c|c|c|c|c|c|}
\hline Değişken & Gözlem & Ortalama & \multicolumn{1}{c|}{ Std. Sapma } & \multicolumn{1}{c|}{ En Küçük } & En Büyük \\
\hline Takıp & 110 & 2.120442 & 1.959062 & 0.009046 & 7.070887 \\
\hline Konut & 110 & 0.3365063 & 0.0691672 & 0.114151 & 0.5212038 \\
\hline Lnıhtıyac & 110 & -1.669189 & 1.399149 & -7.507412 & -0.3971314 \\
\hline Tasıt & 110 & 0.0490073 & 0.0565376 & 0.0014823 & 0.396821 \\
\hline Isyerı & 110 & 0.0741172 & 0.0830909 & 0.002886 & 0.4010613 \\
\hline Tıhtıyac & 110 & 0.5383221 & 0.2676185 & 0 & 0.9442198 \\
\hline Ttasıt & 110 & 0.1989586 & 0.1403842 & 0.0025436 & 0.573977 \\
\hline Ozel & 110 & 0.9715273 & 0.0268457 & 0.859297 & 1.083559 \\
\hline Yurtıcı & 110 & 0.9800815 & 0.0176166 & 0.914645 & 1.081757 \\
\hline Buyume & 110 & 4.290909 & 3.953736 & -4.8 & 9.2 \\
\hline Enf & 110 & 8.158182 & 1.423117 & 6.16 & 10.45 \\
\hline Pfaız & 110 & -1.045455 & 3.424845 & -8.5 & 4 \\
\hline Tldeger & 110 & -0.0892118 & 0.0945549 & -0.2247755 & 0.0498383 \\
\hline Takıplag1 & 110 & 2.279601 & 2.154385 & 0.009046 & 8.290728 \\
\hline Dıgerfaalı D & 110 & 0.0282706 & 0.0139182 & 0.0148827 & 0.1439 \\
\hline Lnaktıf & 110 & -2.676646 & 0.7339831 & -4.779523 & -1.482805 \\
\hline
\end{tabular}

Değişkenlere ilişskin tanımlayıcı istatistikler, Tablo 7'de sunulmuştur. Kriz değişkeni kukla değişken biçiminde tasarlandığından tabloda sunulmamıştır. Tabloya göre, analiz edilen dönem içerisinde örneklem bankalarının takipteki krediler oranı ortalaması \%2.12'dir. Standart sapmanın \%2'ye yakın bir düzeyde şekillenmesi, örneklem bankalarının takipteki krediler oranının birbirine çok yakın olmadığını; dolayısıyla bağımlı değişken anlamında heterojen bir örneklemin seçildiğini göstermektedir. Yine pek çok kredi türünün ana kredi kalemleri içerisindeki oranlarını içeren değişkenlere ilişkin tanımlayıcı istatistikleri incelendiğinde, bankaların farklılaşan kredi tercihlerine sahip oldukları sonucuna ulaşılması mümkün olmaktadır.

\subsection{Analiz Sonuçları}

Panel veri regresyonu analizinin sonuçları Tablo 8'de sunulmuştur. Analiz sabit birim etkiler yöntemi ile gerçekleştirilmiştir. Bunun yanında sabit etkiler modelinin varsayımlarından sabit varyans, otokorelasyonsuzluk ve yatay kesit bağımsızlığı da modelin 
uygulanması öncesinde test edilmiştir. Sabit varyans varsayımı Modified Wald testi vasıtasıyla sınanmış ve modelin sabit varyans varsayımını sağlamadığı dolayısıyla modelde değişen varyans sorununun bulunduğu görülmüştür. Otokorelasyonsuzluk varsayımı Modified Bhargava et al. Durbin Watson (1982) testi ile sınanmış ve modelin otokorelasyon problemi içermediği sonucuna varılmıştır. Son olarak yatay kesit bağımsızlığı Friedman testi ile sınanmış ve modelin yatay kesit bağımlılığı içermediği tespit edilmiştir. Bahsi geçen ve çeşitli testlerle sınanan varsayımların herhangi birinin sağlanamaması durumunda standart hataların düzeltilmesi (dirençli standart hatalar) ile sabit etkiler modeli uygulanabilmektedir. Standart hataların düzeltilmesi dirençli standart hatalar içeren çeşitli tahminciler yoluyla sağlanabilmektedir. Sabit etkiler modelinin varsayımlarından yalnızca sabit varyans varsayımının sağlanamamış olması sebebiyle, değişen varyans altında tutarlı sonuçlar veren Huber, Eicker ve White tahmincisi çalışmada kullanılan tahminci olmuştur (Tatoğlu, 2016:251-252).

Tablo 8 incelendiğinde kurulan modelin içerdiği değişkenlerin, takipteki krediler oranındaki değişimin \%94.79'unu açıklayabildiği görülmektedir. Sonuçlar incelendiğinde, konut ve taşıt kredilerinin tüketici kredileri içerisindeki payı, ticari taşıt kredilerinin ticari krediler içerisindeki payı, enflasyon oranı, önceki dönem takipteki krediler oranı, kriz öncesi veya sonrası dönem olma ve aktif büyüklügünün GSYİH içerisindeki payı değişkenlerinin takipteki krediler üzerinde istatistiki açıdan anlamlı bir etkiye sahip olduğu görülmektedir. Katsayılar incelendiğinde, konut kredilerinin tüketici kredileri içerisindeki payı, ticari taşıt kredilerinin ticari krediler içerisindeki payı, ve kriz sonrası dönem olma değişkenlerinin takipteki krediler oranının aşağı çektiği; bununla birlikte taşıt kredilerinin tüketici kredileri içerisindeki payı, enflasyon, bir önceki dönem takipteki krediler oranı ve aktif büyüklügüünün GSYİH'ye oranı değişkenlerinin takipteki krediler oranını yukarı çektiği sonucuna varılmaktadır. Diğer politika değişkenleri olan ihtiyaç kredilerinin tüketici kredileri içerisindeki payı, işyeri ve ticari ihtiyaç kredilerinin ticari krediler içerisindeki payı, özel sektöre ve yurtiçine kullandırılan kredilerin toplam krediler içerisindeki payı değişkenlerinin takipteki krediler oranı üzerinde istatistiki açıdan anlamlı bir etkisine rastlanılamamıştır. Yine kontrol değişkenlerinden büyüme, politika faizi, Türk Lirası'nın değeri, diğer faaliyet giderlerinin aktiflere oranı değişkenlerinin takipteki krediler oranı üzerinde istatistiki açıdan anlamlı bir etkisinin bulunmadığı anlaşılmıştır.

Tablo 8. Sabit Etkiler Modeli Panel Veri Regresyonu Sonuçları

\begin{tabular}{|c|c|c|c|c|}
\hline \multicolumn{7}{c}{ Bağımlı Değişken: Takipteki Krediler Oranı } \\
\hline Değişkenler & Katsayı & Std. Sapma & T-İstatistiği & P Değeri \\
\hline Konut & -3.381668 & 0.4193224 & -8.06 & $0.000^{* * *}$ \\
\hline Lnıhtıyac & -0.0364929 & 0.0465566 & -0.78 & 0.453 \\
\hline Tasıt & 3.396233 & 1.037144 & 3.27 & $0.010^{* * *}$ \\
\hline Isyerı & -0.9699329 & 1.517406 & -0.64 & 0.539 \\
\hline Tihtıyac & -0.7492487 & 0.5967978 & -1.26 & 0.241 \\
\hline Ttasıt & -2.014425 & 1.054582 & -1.91 & $0.088^{*}$ \\
\hline Ozel & 2.765113 & 1.812121 & 1.53 & 0.161 \\
\hline Yurtıcı & 4.398392 & 3.403962 & 1.29 & 0.228 \\
\hline Buyume & 0.0057418 & 0.0189718 & 0.30 & 0.769 \\
\hline Enf & 0.1684958 & 0.0554828 & 3.04 & $0.014 * *$ \\
\hline Pfaiz & 0.0113889 & 0.023243 & 0.49 & 0.636 \\
\hline Tldeger & -0.4849577 & 0.862828 & -0.56 & 0.588 \\
\hline
\end{tabular}




\begin{tabular}{|c|c|c|c|c|}
\hline Takıplag1 & 0.7396728 & 0.0490721 & 15.07 & $0.000 * * *$ \\
\hline Digerfaalıyetgıd & 1.482459 & 5.141619 & 0.29 & 0.780 \\
\hline Dumcrisis & -0.3037587 & 0.1133319 & -2.68 & $0.025 * *$ \\
\hline Lnaktıf & 1.28396 & 0.1919437 & 6.69 & $0.000 * * *$ \\
\hline Cons & -2.591173 & 3.369759 & -0.77 & 0.462 \\
\hline \multicolumn{5}{|c|}{$\begin{array}{l}\text { 1) } R^{2}=0.9479 \quad \text { Prob. }>F=0.0000 \\
\text { 2)Modified Wald Test } P=0.0000 \\
\text { 3)Modified Bhargava Et } A l . \text { Durbin-Watson }=2.3645665 \text { / Baltagi-Wu Lbı }=2.5246494 \\
\text { 4) Friedman Yatay-Kesit Bağımsızlığ Test İstatistiği }=12.309, P=0.1964\end{array}$} \\
\hline $\begin{array}{ll}* & \mathrm{p}<0.1 \\
* * & \mathrm{p}<0.05 \\
* * * & \mathrm{p}<0.01\end{array}$ & & & & \\
\hline
\end{tabular}

\section{SONUÇ VE ÖNERILER}

Genel bir değerlendirme yapılırsa, maddi varlık ipoteği ve rehnine bağlı krediler olan konut kredileri ve ticari taşıt kredilerinin ana kredi grupları içerisindeki payının yüksek olduğu bankaların takipteki krediler oranının daha düşük olduğu sonucuna varılmaktadır. Analiz sonuçlarına göre her ne kadar maddi duran varlık rehnine dayalı bir kredi olan taşıt kredilerinin tüketici kredileri içerisindeki payının artışı beraberinde daha yüksek takipteki krediler oranını getiriyor gözükse de; istatistiki olarak anlamsız olan işyeri kredilerinin ticari krediler içerisindeki payı ile birlikte istatistiki açıdan anlamlı diğer tüm maddi varlık teminatına dayalı ve bunlar üzerine kullandırılan kredilerin payları arttıkça takipteki krediler oranının da bunlarla birlikte azalıyor oluşu, varlığa dayalı (varlık temelli- asset based, asset backed) kredilerin ödenmemeye karşı daha dirençli olabileceği yorumunu yapmamıza olanak tanımaktadır.

Nitekim 2000'lerin başında varlık temelli kredilendirme (asset-based lending), taşraya ve küçük şirketlere özgü bir ürün olmaktan çıkıp, bir tür büyük ticari şirket ürünü olma dönüşümünü geçirmiştir. Çünkü geleneksel bankacılık anlayışındaki kredilendirme değerlendirmesi, şirketin likit ya da daha geniş kapsamıyla dönen varlıkları üzerinden hesaplanan ödeme gücüne odaklanırken; varlık temelli kredilendirme ödeme gücü ölçüsü olarak şirketin dönen varlıkları yanında duran varlıklarına da odaklanmaktadır. $\mathrm{Bu}$ sayede şirketler, kısa süreli likidite sıkışıklıklarından duran varlıkları ile teminatlandırdıkları krediler ile kurtulup yeniden ödeme gücüne kavuşabilmektedirler (Bank of America Merrill Lynch, 2015:1-2).

Yine varlık temelli kredilerin ticari işletmeler için sağladığı kolaylık ve likiditeyi güçlendirme etkisinin yanında, varlık temelli bir bireysel kredi türü olan konut kredilerinin de banka kredi portföyünde aşırı yoğunlaşma yaratmadığı takdirde finansal düzensizliği ve riski aşağ 1 çektiği görülmektedir. Morgan ve Zhang (2015), konut kredilerinin, kredi çeşitlendirmesine zarar vermeksizin artışının takipteki kredi oranını ve bununla birlikte finansal istikrarsızlığı aşağ 1 çektiğini belirtmektedir.

Ayrıca makro değişkenlerin takipteki krediler üzerinde anlamlı etkisini görmek mümkündür. Analiz sonuçlarına göre, enflasyondaki artış takipteki krediler oranını da belli bir miktar yukarı çekmektedir. Bu bulgu çalışmanın başında da yer verildiği üzere finansal 
istikrar-kredi riski ilişkisi noktasında anlamlı gözükmektedir. Çünkü takipteki krediler oranının ekonominin genel gidişatının kötü olduğu dönemlerde yükseldiği ve istikrarlı bir ortamda aşağı doğru şekillendiği ilk bölümde dile getirilmişti. Yüksek enflasyonun ekonomide tahmin edilebilirliği azaltıcı etkisi, takipteki krediler oranının yükselmesine sebep olabilmektedir. Yine analiz sonuçları, kriz sonrası yıllarda bankaların takipteki kredi oranlarının azalış yönünde bir trend içinde olduğunu ortaya koymaktadır. $\mathrm{Bu}$ durumun bankaların 2009 krizi sonrası kredi riskinin kontrolü yönünde aldığı önlemlerin bir sonucu olma ihtimali yüksektir.

Analiz sonuçlarına göre bankaların aktif büyüklüklerinin hızlı artışı beraberinde yüksek kredi takip oranını getirmektedir. Bu noktada agresif pazarlama yöntemleriyle hızlı aktif büyümesi sağlamaya yönelik politikaların yüksek kredi riski potansiyeline sahip olabileceği yorumunu yapmak mümkündür.

Önceki dönem takipteki krediler oranı ile cari dönem takipteki krediler oranı arasındaki anlamlı ve pozitif yöndeki ilişki, yüksek takipteki kredi oranının bankalar için kısa sürede çözülmesi mümkün olmayan bir problem olduğunu ortaya koymaktadır. Bir önceki dönem yüksek kredi riskine sahip bir banka büyük olasılıkla bir sonraki dönemde de yüksek kredi riskine sahip olmaktadır. Bu yönüyle değerlendirildiğinde bankaların takipteki kredi oranlarını düşürmek için istikrarlı ve uzun süreli kredi risk yönetimi politikaları ihtiyacının olduğu görülmektedir.

Sonuç olarak Türk mevduat bankaları üzerinde gerçekleştirilen analiz, varlık teminatlı kredilerin takipteki krediler oranı üzerinde anlamlı bir etkisi olabileceği düşüncesini ortaya koymuştur. Finansal sektörde kullanımı artan varlık-temelli kredilendirmenin sağladığ avantajlar ve konut kredilerinin finansal istikrar üzerindeki etkisine yönelik çalışmalar da söz konusu etkinin politika kararlarında dikkate alınmasının faydalı olabileceği algısını kuvvetlendirmektedir. Bu yönüyle değerlendirildiğinde, bankacılık sektöründe varlık temelli kredilendirmeye uygun kredi ürünlerinin fon ihtiyacı olan tüketicilere ve ticari işletmelere sunulmasının kredi riskini daha alt düzeye çekme noktasında faydalı olabileceği düşünülmektedir. Yine hızlı aktif büyümesinin kredi riskine olan etkisi sebebiyle, bankaların pazarlama politikalarının daha ihtiyatı bir yöne çekilmesinin kredi riski yönetiminde etkili olabileceği sonucuna varmak mümkündür. Son olarak kredi riskinin aşağ 1 düzeylere kalıc1 olarak çekilebilmesi için, bankaların uygulayacağ vadeli ve iyi planlanmış politikalar olması gerektiği düşüncesi öne çıkmaktadır. 


\section{KAYNAKLAR}

Abdioğlu, Nida - Aytekin, Sinan (2016), "Takipteki Kredi Oranını Etkileyen Faktörlerin Belirlenmesi: Mevduat Bankaları Üzerinde Bir Dinamik Panel Veri Uygulaması", İşletme Araştırmaları Dergisi, 8, 1,ss. 538-555.

Anastasiou, Dimitrious - Louri, Helen - Tsionas, Mike Efthhymios (2016), "Determinants of Non-Performing Loans: Evidence from Euro-Area Countries", Finance Research Letters, 18, pp. 116-119.

Anastasiou, Dimitrious - Louri, Helen - Tsionas, Mike Efthhymios (2016), "Non-Performing Loans in the Euro Area: Are Core-Periphery Banking Markets Fragmanted?", Bank of Greece Working Paper, http://www.bankofgreece.gr/BogEkdoseis/Paper2016219.pdf (01.09.2017).

Bank of America Merrill Lynch (2015), A Guide to Asset-Based Lending, https://www.bofaml.com/content/dam/boamlimages/documents/articles/C2_009/guide _to_asset-based_lending.pdf (17.08.2017).

Berger, Allen N. - DeYoung, Robert (1997), "Problem Loans and Cost Efficiency in Commercial Banks", Journal of Banking and Finance, 21, 6, pp. 849-870.

Bhargava, Alok - Franzini Luisa - Narendranathan, Wiji A.N.(1982), "Serial Correlation And The Fixed Effects Model”, Review of Economic Studies, 49, 4, pp. 533-549.

Breuer, Janice Boucher (2006), "Problem Bank Loans, Conflicts of Interest, and Institutions", Journal of Financial Stability, 2, 3, pp.266-285.

Curak, Marijana - Pepur Sandra - Poposki, Klime (2013), "Determinants of Non-Performing Loans - Evidence from SoutheasternEuropean Banking Systems", Banks and Bank Systems Journal, 8, 1, pp. 45-53.

Dickey David A. - Fuller, Wayne A.(1979), "Distribution of the Estimators for Autoregressive Time Series with a Unit Root", Journal of the American Statistical Association, 74, 366, pp. 427-431.

Gujarati, Damodar N.(2006), Basic Econometrics (4th edt.),McGraw Hill, New York.

Hou, Yixin (2007), "The Non-performing Loans: Some Bank-level Evidences", The 4th Advances in Applied Financial Economics, the Quantitative and Qualitative Analysis in Social Sciences Conferences.

Im Kyung So - Pesaran M.Hashem - Shin Yongcheol(2003), "Testing for Unit Roots in Heteregeneous Panels", Journal of Econometrics, 115, 1, pp.53-74.

Keeton, William R. - Morris, Charles S. (1987), "Why Do Banks' Loan Losses Differ?", Federal Reserve Bank of Kansas City Economy Review, 72, 5, pp. 3-21. 
Levin Andrew - Lin Chien Fu - Chu James, Chia-Shang (2002), "Unit Root Tests in Panel Data: Asymptotic and Finite- Sample Properties", Journal of Econometrics, 108,1, pp. $1-24$.

Macit, Fatih - Keçeli, Betül (2012), “Takipteki Kredi Oranını Etkileyen Faktörler: Türkiye'de Katılım Bankaları Örneği”, Avrasya İncelemeleri Dergisi, 1,1, ss. 193-207.

Makri, Vasiliki - Tsagkanos, Athanasios - Bellas, Athanasios (2014), "Determinants of NonPerforming Loans: The Case of Eurozone", Panoeconomicus Journal, 2, pp. 193-206.

Mensah, Franklin Amuakwa - Marbuah, George - Marbuah, Dinah Ani-Asamoah(2017), "Reexamining the Determinants of Non-Performing Loans in Ghana's Banking Industry: Role of the 2007-2009 Financial Crisis", Journal of African Business, 18, 3, pp. 357379 .

Morgan, Peter J. - Zhang, Yan (2015), "Mortgage Lending and Financial Stability in Asia", Asian Development Bank Working Paper, https://www.adb.org/sites/default/files/publication/173102/adbi-wp543.pdf (03.10.2017)

Messai, Ahlem Selma - Jouini, Fathi (2013), "Micro and Macro Determinants of Nonperforming Loans", International Journal of Economics and Financial Issues, 3, 4, pp. 852-860.

Rajha, Khaled Suphi (2016), "Determinants of Non-Performing Loans: Evidence from the Jordanian Banking Sector", Journal of Finance and Bank Management, 4,1, pp.125136.

Rinaldi Laura, Sanchis-Arellano Alicia (2006), "Household Debt Sustainability: What explains Household Non-performing Loans? An Empirical Analysis", European Central Bank Working Paper, https://www.ecb.europa.eu/pub/pdf/scpwps/ecbwp570.pdf?2546b8e 00ce934b13cfe47c36da5bc45 (03.10.2017).

Sevüktekin, Mustafa (2013), Ekonometriye Giriş, Dora Yayınevi, Bursa.

Skarica, Bruna (2014), "Determinants of Non-Performing Loans in Central and Eastern European Countries", Financial Theory and Practice, 38,1, pp. 37-59.

Tanaskovic, Svetozar - Jandric, Maja (2015), "Macroeconomic and Institutional Determinants of Non-Performing Loans", Journal of Central Banking Theory and Practice, 4,1, pp. 47-62.

Tatoğlu, Ferda Yerdelen (2016), Panel Veri Ekonometrisi, Beta Yayınevi, İstanbul.

Us, Vuslat (2016), "Determinants of Non-Performing Loans in the Turkish Banking Sector: What Has Changed After the Global Crisis?", TCMB Research Notes in Economics, No.16/27, pp. 1-14. 
Us, Vuslat (2017), "Dynamics Of Non-Performing Loans in The Turkish Banking Sector By An Ownership Breakdown: The İmpact Of The Global Crisis", Finance Research Letters, 20, pp. 109-117.

Vatansever, Metin - Hepşen, Ali (2013), "Determining Impacts on Non-Performing Loan Ratio in Turkey", Journal of Finance and Investment Analysis, 2,4, pp. 119-129.

www.tbb.gov.tr

www. tuik.gov.tr

Yağcılar, Gamze Göçmen - Demir, Semra (2015), “Türk Bankacılık Sektöründe Takipteki Kredi Oranları Üzerinde Etkili Olan Faktörlerin Belirlenmesi”, Uluslararası Alanya İşletme Fakültesi Dergisi, 7, 1, ss. 221-229. 